(昭和 38 年 1 月 5 日受理)

$$
\text { ナイロンおよび“テトロン”繊維のスキン・コア棈造 }
$$

$$
\text { 東洋レーシン株式会社加藤蓠一・山本茂・吉村堅㳄 }
$$

\title{
SKIN-CORE STRUCTURE OF NYLON AND “TETORON" FIBERS
}

By Kȫichi Kato, Shigeru Yamamoto and Kenji Yoshimura

(Toyo Rayon Co. Ltd., Ōtsu City, Shiga-Prefecture, Japan)

A new technique for the differential staining of the skin-core structure of nylon yarn crosssections is described. The technique is different from the method recently developed by W.R. Berry in that a single metal-complex dye, Lanasyn Grey BL (Sandoz), is used instead of a combination of two dyes, Kiton Pure Blue V, an acid dye, and Methyl Violet 2B Supra I, a basic dye. According to the staining and differentiation procedures applied one can obtain either the skin staining or the core staining in a highly reproducible manner.

It is evident that a distinct skin-core structure is present in nylon filament, both undrawn and drawn, and that the outer skin portion always permits the dye to enter and leave much more readily than the inner core portion.

A similar structure can also be revealed in "Tetoron" polyester fiber cross-sections. Disperse dyes were used to stain slide preparations with or without carrier, followed by washing with trichlorethylene. It was, however, difficult to get a sufficiently deep staining of the cross-sections, in particular of drawn yarns.

(Received January 5, 1963)

緒 言

テイロン 6 执よびナイロン 66 系の切片に就るスキ

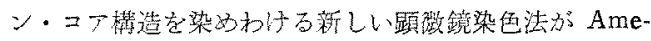
ikan Enka 社の W.R. Berry によって発表された1)。 この方法性酸性沎料 Kiton Pure Blue V と塩基性染料 Methyl Violet 2B Supra I t傡用して和り, 徒来ナイ

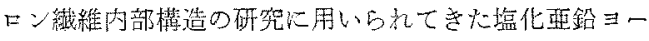

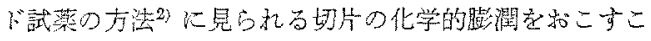
となく，正賞状態でのスキン・ュア棈造の锶察安可能に するもの之主張されている。

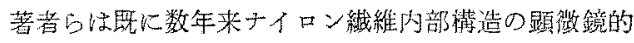

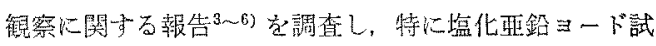

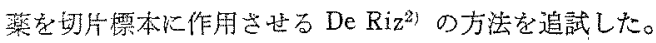
しかし Berry の指摘しているよらに，この場合子イは ン糸切片は試蓃により著しく膨潤し，その膨潤の過程に 蛙いて特有な大キン棈诰が出琴するので，安定な形でこ

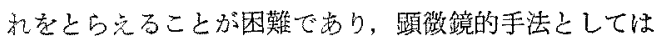
適当でない多のと判断した。そのためナイロン用の錯塩 染料の1種である Lanasyn Grey BL (Sandoz) を用い

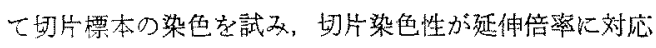

して買著に变化するとともに一種のスキン・コア的染め わけの得られることを認めた。

今回 Berry の方法の発表に関連してこの方法に改め て検討を加觉染色操作条件を決定し，同時は染色結果に ついて若下の洘察を叔こったのてここに報些する。ま

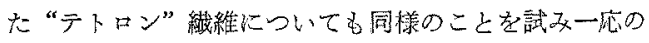
成果を得てので併过て記述寸る。なお本報告の要旨は Text. Res.J. に速遐の形で発表されている7。

\section{第1部ナ1ロン}

ナイロン糸切片の染色珄は未延伸系之延伸系で非常沉 差加すりまたナイロン6とナイロン 66 との間で尚差

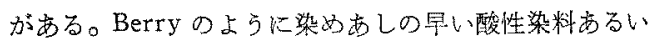

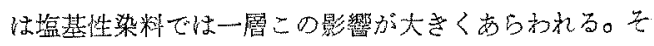
のため Berry はナイロン 6 とナイロン 66 とに対して

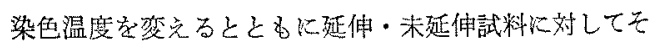
れぞれ染色時間そ秒単位で指定している。

これに対して著者らは意識的に染めあしの沶々い染料 を選定して染色操作定安定化し, 結果の再現性孝高める ことをはかった。

切片標本 


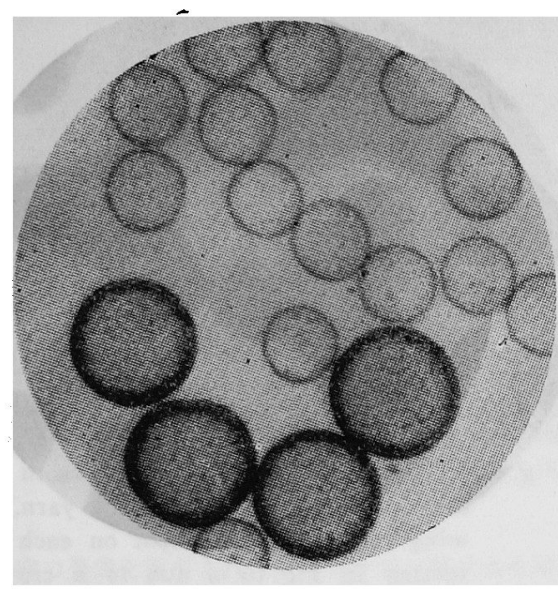

Fig. 1. Skin staining on nylon 6 undrawn yarn. $400 \times$ The adjacent cross sections of drawn yarn are still almost unstained.

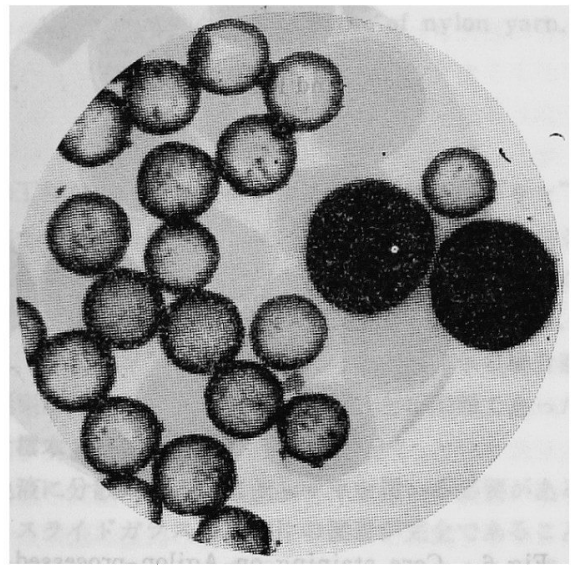

Fig. 2. Skin staining on nylon 6 drawn yarn. $400 \times$ The cross sections of undrawn yarn are completely stained.

厚さ 5 ミクロンととする。寒天パラフィン改良包埋法 ${ }^{8)}$ によるのが当然良質の標本を作るのに適するが，エチル セルロース・パラフィン・ステアリン酸混合直接包埋 法8)でもナイロンの場合十分目的を達し得る。脱包埋は キシレンで括こなら。

染色 液

中性染錯塩酸性染料 Lanasyn Grey BL を 1\% 水溶 液として用いる。

\section{染色法およひ染色結果}

完成標本における染着部位に対応してスキン染色とコ ア染色に区分される。前者ではコアがまだ染まらない状 態に残ってお゙り，後者ではスキンが一染染まったのら脱

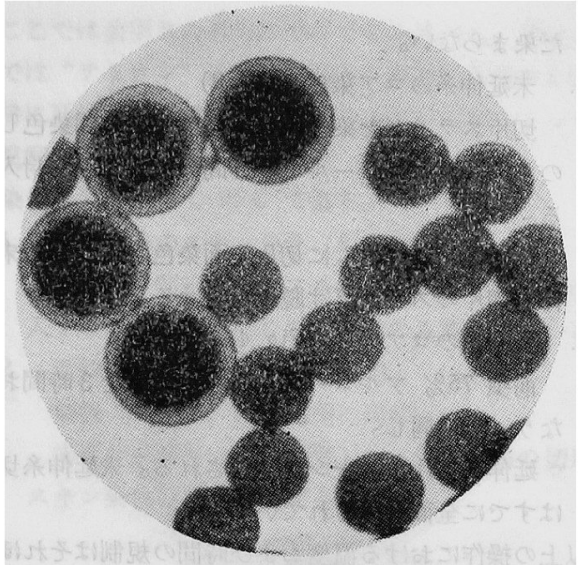

Fig. 3. Core staining on nylon 6 undrawn yarn. $400 \times$ The cross sections of drawn yarn are still undifferentiated.

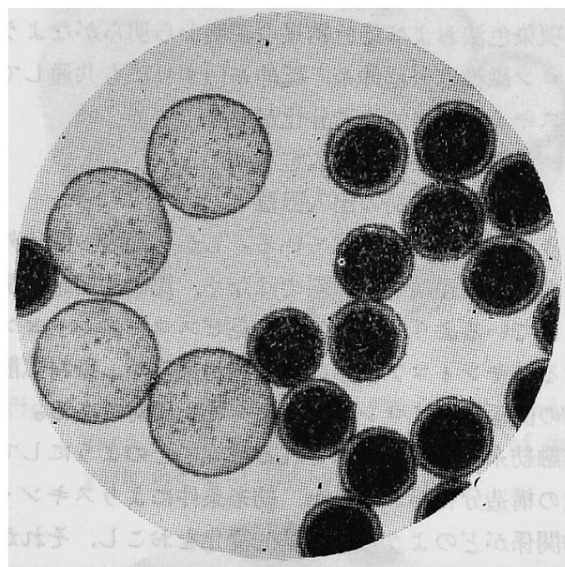

Fig. 4. Core staining on nylon 6 drawn yarn. $400 \times$ The cross sections of undrawn yarn are already completely washed off.

色された状態である。Fig.1〜4 ではナイロン6の未延 伸系と延伸系の切片が同時包埋法によって同一視野内に 颃いて比較されている。

1. 未延伸系のスキン染色 (Fig. 1)

切片スライド上に染色液をたっぷりのせ，熱板上 で加温染色 1 分間ののち染液をすて，90\%アルコー ルで洗い, 脱水封入する。

未延伸系切片のスキンが濃染し、コアは汪とんど 染まらない。延伸糸切片は全然不染のままである。

2. 延伸糸のスキン染色 (Fig. 2)

前項の加温染色を 5 分間括こなう。他の操作は同

じ。未延伸糸切片は全面染まり, 延伸糸のコアはま 
だ染まらない。

3. 未延伸系のコア染色 (Fig. 3)

切片スライドを染色液中で煮沸 30 分間染色した のち, $75 \%$ アルコールで 5 分間分色し, 脱水封入す る。

未延伸, 延伸ともに切片全面染色されたのち未延 伸糸切片のスキンだけ脱色を受ける。

4. 延伸系のコア染色 (Fig. 4)

前項 $75 \%$ アルコールによって分色を 3 時間扮こ なら。他は同じ。

趧伸系切片のスキンが分色される。未延伸系切片 はすでに全面脱色されている。

以上の操作に㧍ける温度および時閒の規制はそれほど 祣密を要しない。大体の標準を示したにすぎない。ナイ ロン 66 の場合はその低染色性に应じて染色および分色 の条件をか烈にする必要がある。

考察

前頃染色法和よび染色結果の説明から明らかなように ナイロン繊維は末延伸系, 延伸糸いずれにも共通して一 種のスキン・コア的構造分化か゚あり

スキン：染料の出入容易

ב.ア：染料の出入困難

といら相対的な差を示している。しかし両者の間は外周 から中心への連続的な傾斜ではなく，比確的明確な境界 をとっているように見える。一見ビスコースレーヨンに おけるスキン・コア構造に似た感があるが，染料拡散の 難易の関係はナイロンとレーヨンで正反詨である。

溶融紡糸によって紡糸される瀻維にどのようにしてこ の種の構造分化がおこるか, 紡糸条件によりスキン・コ ア的関係がどのような質的量的変化を扣こし，それが緎 維の最終用途的性質にどのように関連するかなどの実際 的な問題は今後の解明にまたなけ礼ばならない。

Berry の方法は酸性, 塩基性両種の染料を組合わせて 用いているが，それが生物組織学に牧けるいわゆる二重 染色の意義を持つものでないことは明白である。その染 色結果は本質的に上述したスキン染色㑑当するもの で，特に Methyl Violet がスキン層に対して選択的に 染着した瞬間を捕える形をとっている。染色時間を秒単 位で婗制し，さもなければ得られる結果が甚しく変動す ることは顕微鏡的手法としてあまり望ましいものではな いであるう。ただ Kiton Pure Blue による青色の染色 を重複させることによる標本の色彩効果は鮮明である。

\section{店用例}

Fig. 5 異形断面ナイロン系におけるコア染色 正常円形系の場合之同様である。

Fig. 6 Agilon 加工糸に推けるコア染色

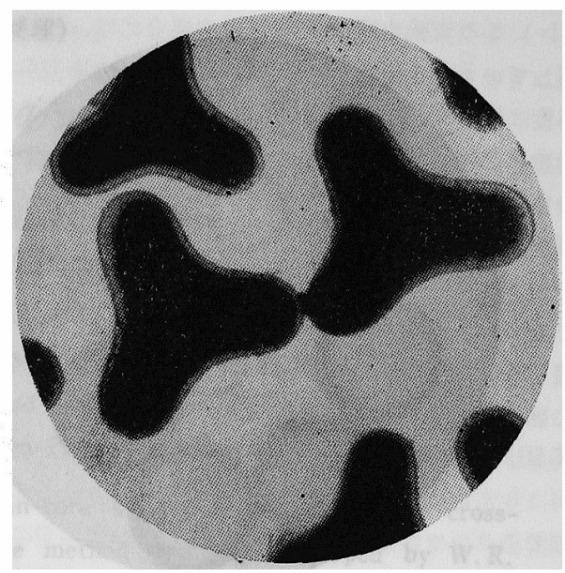

Fig. 5. Core staining on trilobal nylon 66 filaments. $400 x$

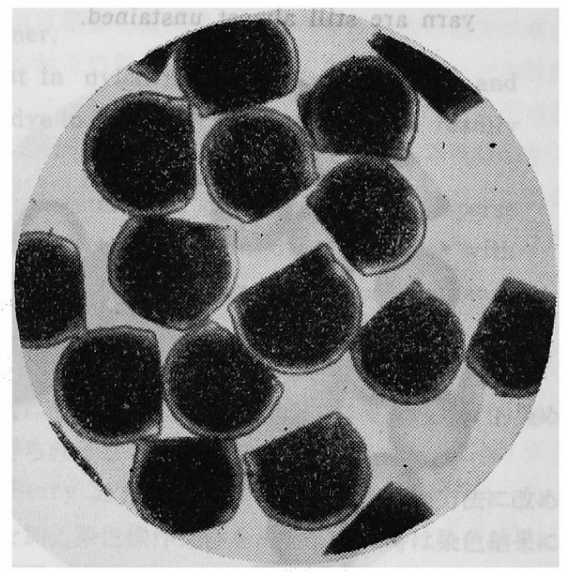

Fig. 6. Core staining on Agilon-processed nylon 6 yarn. $400 \times$ Each filament is seen as laterally shaved off.

この加工工程では単なる変形でなく、繊維の一部 が削り取られていることが切片染色の結果確認され る。

Fig. 7 特殊加工糸に护けるコア染色

テイロン靴下の吸水性括よび風合改善をねらった 加工法々いわれるもので, コア層が偏心的に縮小七 ている。

\section{絨維状染色法}

Lanasyn Grey BL による染色とアルニールによる 分色の操作は瀻維状試料の形で適用し，そのあと邚片 としてもかなりの程度切片染色の結果とよく対応した 結果が得られるので簡便法として有効に利用し得る分 野があるであるら。 


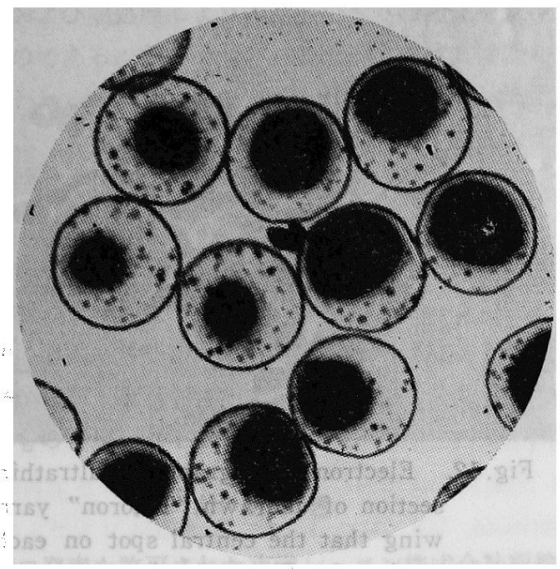

Fig.7. A peculiar sort of skin-core relationship revealed on a nylon 6 sample $400 \times$ It was said that the sample had been derived from a special processing for improving the absorbency and handle of nylon yarn.

\section{第 2 部 “テトロン”}

紡糸工程から類推してポリエステル瀻維 “テトロン” にすナイロンと同様なスキン・コア的構造が存在し，こ れ対してナイロンの場合と全く同形式の染めわけ法が 可能であろうと予想された。この予想は確認されたが, 一般に “テトロン”の難染性のため特に延伸系の場合顕 铔鏡観察に充分な程度の染色を得ることが困難であった。 切片標本

染色液に分散剈あるいはキャリヤを用いる必要がある ため, スライドガラスへの切片の接着が完全であること が要求される。そのため寒天パラフィン法による良質の 標本を作製することが望ましい。

染色液

次の 2 種の処方を比較した。

A. キャリヤなし

Celanthrene Brilliant Blue FFSK 300\% 1\% ラパールD $0.5 \%$

B. キャリヤあり

Duranol Dark Blue

Carrier E

$30 \%$ ラハンール液 $1 \%$ $1 \%$

Bのほらが染色が迅速で濃色が得られるので推奖され る。先のかわり標本が污染しやすいこと，染液の再使用 が不可能なことが欠点となる。染液は調製後濾過して使 用するのがよい。

\section{染色法および染色結果}

ここでは前項Bの処方についてのみ述べる。Fig.8〜 11では “テトロン” 未延伸試料とこれを約 3 倍および約 4 倍に延伸した 3 種の試料の切片が同時包埋によって同 一視野内に比較されている。

染色温度はずべて $95^{\circ} \mathrm{C}$ である。

1. 米延伸系のスキン染色 (Fig. 8)

染色 3 分間後水洗，アルコール系列を経て脱水封 入する。未延伸紛片のスキンのみ染まっている。

2. 延伸系のスキン染色 (Fig. 9)

染色 30 分間，あ之前項に同し。

未延伸系切片は全面濃染し４倍延伸系の切片が スキン染色の状熊を呈する。

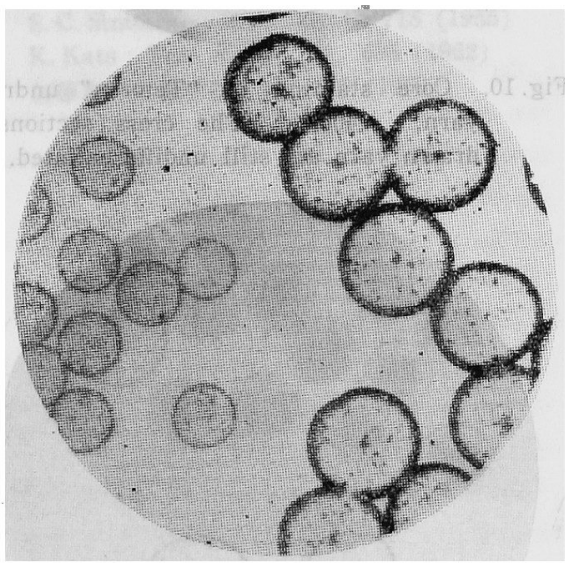

Fig. 8. Skin staining on "Tetoron" undrawn yarn. $400 \times$ The cross sections of drawn yarn are still almost unstained.

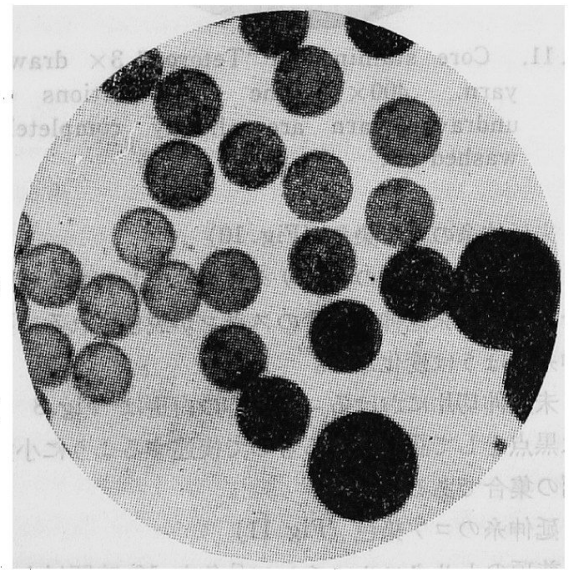

Fig. 9. Skin staining on "Tetoron" $4 \times$ drawn yarn. $400 \times$ Both undrawn yarn and $3 \times$ drawn yarn are already more or less evenly stained. 


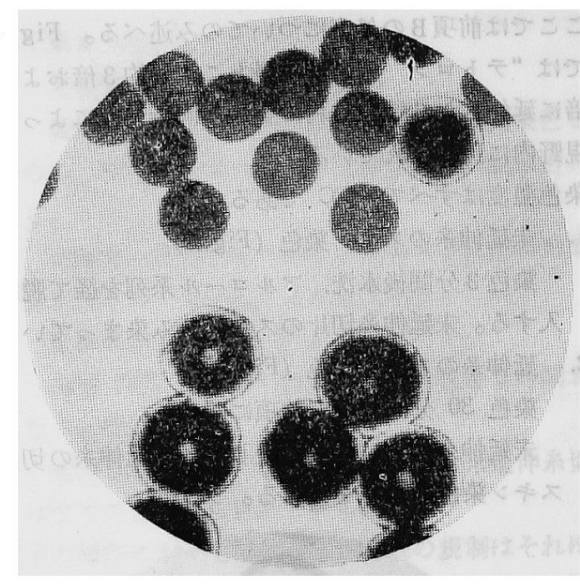

Fig. 10. Core staining on "Tetoron" undrawn yarn. $400 \times$ The cross sections of drawn yarn ars still undifferentiated.

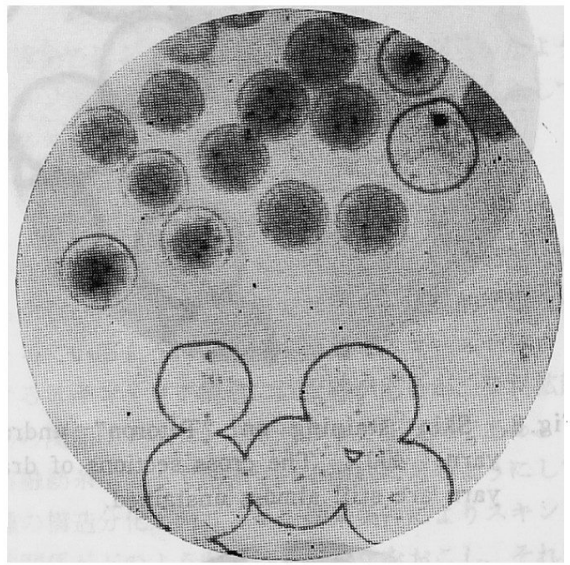

Fig. 11. Core staining on "Tetoron" $3 \times$ drawn yarn. $400 \times$ The cross sections of undrawn yarn are already completely washed off.

\section{3. 未延伸糸のコア染色 (Fig.10)}

染色 30 分間ののちトリクロルエチレンで 2 時間 分色する。未延伸糸切片のスキンが脱色される。延 伸糸のほ 5 は変化なし。

未延伸切片に叔けるア中心の白斑は Fig.8 で は黒点として認められるもので後述するように小空 洞の集合である。

4. 延伸糸のコア染色 (Fig. 11)

前項のトリクロルエチレン分色を 10 時間以上施 したもの。未延伸系切片は完全に脱色し，3倍延伸 糸切片で不完全なコア染色を呈している。

本染色法では染色をこれ以上継繶して山延伸系切片の

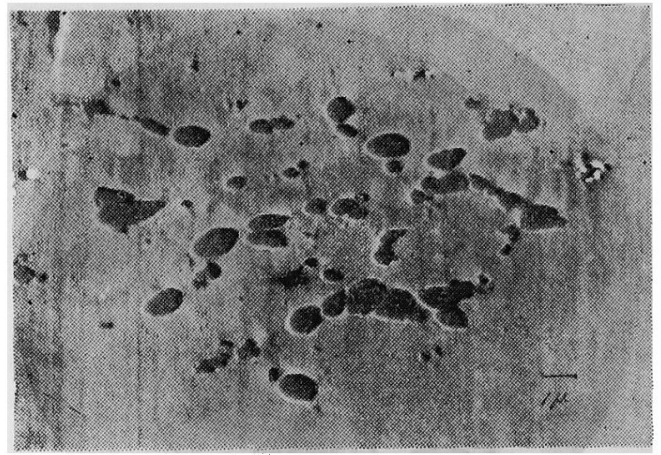

Fig. 12. Electron micrograph of ultrathin cross section of undrawn "Tetoron" yarn, showing that the central spot on each cross section in Fig. 10 is due to a crowd of small voids, the nature of which is, however, not yet known. $\mathrm{Cr}$ shadowing $3: 1$.

染着は強化されない。従って不完全なスキン染色を得る のがようやくであってコア染色は成功しない。今後検討 を加完る必要がある。

\section{考察}

“テトロン”、についての染色結果の解橎はナイロンの 場合と全く同一と見てよいであろう。染色条件が満足で ないので断定は避けなければならないが “テトロン”の スキン・コア分化は未延伸系ではかなり明瞭であるが延 伸を受けるとかなり不明瞭となるようである。

Fig. 12 は “テトロン”来延伸系の超薄切片電子顕微 鏡写真である。Fig.8 扎よび Fig. 10 に現われている中 心部の構造が䋐維の中心に集った小さい空洞の集合体で あることを証明している。この種の構造が延伸糸では完 全に消失していることは興味深い。

\section{䄉維状染色法}

ナイロンの場合と同様に“テトロン”でも㵶維状のま まで染色执よび分色を施してしかるのち切片とする方式 により適当な考慮さえ払壳ぱ切片染色の所見とよく対応 した結果を得ることができる。これはビスコースレーヨ ンのスキン対コアの関係と異なり，ナイロン拈よび“テ トロン”では外周のスキン層に対する染料の出入が内部 のコアより容易な関係にあるためである。

標本作製の各段階においてナイロンに比べ困難な点の 多い“テトロン”では特にこの瀻維状染色法の利用は実 用的な価値が大きいものと思われる。

\section{ま と め}

ナイゅンおよび“テトロン”に共通的に見出されるス キン・ゴ構造は溶融紡系の過程に抬いて発生し, その 
あと延伸括よび熱処理により大なり小なりの変化を受け て行くものであるにちがいない。また最近ますます盛ん 比扰こなるれる二次加工化执いても機械的あるいは物理 的作用化よりスキン・コラ゙的構造所見が大きく变化を受 けることが芳えられる。

元来䫒微鏡的にほとんど無構造に近いるのと見られて いたこれら溶融紡系合成䋊維に扣けるこの種の観察は形 熊学的に極わて単継なるのであるたけに製造および加工 上の各種の要因之最終製品の物理的方るい化学的性質 との間のつながりを解析するのに便利な手ががりのつ を与克るものと思われる。

\section{あとがき}

本研究の発表を許可された東洋レーヨン株式会社取䋨 役技術研究部長小林治男博士に感謝する。染料の選択拉
よび染色法の設定に関して当社技術サービス部染色研究 所小島弥一氏から多大のご教示を得た。ここ付記して 深謝する次第である。

な扣本研究は緎維学会昭和 37 年春期および秋期研究 発表会に㧊いて発装したものである。

文献

1) W.R.Berry ; Text.Res.J., 31, 810 (1961)

2) O. De Riz et a1. ; Melliand Textilber., 36, 680 (1955)

3) J.M.Preston ; J. Text.Inst., 41, T 126 (1950)

4) H.J. Woods ; ibid., 46, T 629 (1955)

5) M.V. Forward, S.C. Simmens; ibid., 46, T 671 (1955)

6) S.C. Simmens; ibid., 46, T 715 (1955)

7) K. Kato ; Text.Res.J., 32, 695 (1962)

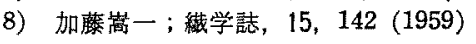

